\title{
Evaluation of QoI Fungicide Application Strategies for Managing Fungicide Resistance and Potato Early Blight Epidemics in Wisconsin
}

\author{
N. Rosenzweig and Z. K. Atallah, Department of Plant Pathology, University of Wisconsin, Madison 53706; \\ G. Olaya, Syngenta Crop Protection Inc., Vero Beach Research Center, Vero Beach, FL 32967; and W. R. Steven- \\ son, Department of Plant Pathology, University of Wisconsin, Madison
}

\begin{abstract}
Rosenzweig, N., Atallah, Z. K., Olaya, G., and Stevenson, W. R. 2008. Evaluation of QoI fungicide application strategies for managing fungicide resistance and potato early blight epidemics in Wisconsin. Plant Dis. 92:561-568.

Potato early blight (Alternaria solani) is a yield-limiting disease and control depends primarily on multiple fungicide applications. Azoxystrobin, registered in the United States in 1999, initially provided outstanding early blight control. Within 3 years, approximately $80 \%$ of the total potato acreage was being treated with azoxystrobin and other quinone outside inhibitor (QoI), fungicides registered subsequently. Alternaria solani isolates with decreased in vitro sensitivity to azoxystrobin were detected in Wisconsin during 2001. Field experiments were conducted in 2001 to 2003 to evaluate season-long fungicide programs and test fungicide resistance management strategies. The fungicide program recommended to growers at that time, which consisted of three applications of azoxystrobin for weeks 1, 3, and 5 alternated with applications of chlorothalonil at label recommended rates, was effective in controlling early blight when conditions were conducive to disease development. Mean sensitivity in vitro of $A$. solani isolates from fungicide efficacy field experiments in 2001 to 2003 was numerically highest for isolates from the untreated control plots, chlorothalonil-alone plots, or plots treated with three applications of azoxystrobin alternated with chlorothalonil compared with other treatments tested. Three singlenucleotide polymorphisms (SNPs) can cause the F129L substitution (TTC to TTA, CTC, or TTG) that results in decreased sensitivity to azoxystrobin of A. solani. The TTA mutant was the most frequently recovered mutant type in the field experiments. The frequency of recovery of wild-type isolates in experiments was $22 \%$ in 2001, 4\% in 2002, and 22\% in 2003.
\end{abstract}

Additional keywords: quantitative PCR

Potato early blight, caused by the polycyclic Fungi Imperfecti Alternaria solani Sorauer, is an annual production concern for commercial potato growers in Wisconsin in years with intermittent wet and dry periods, especially in areas with overhead irrigation and frequent dew where disease pressure becomes particularly intense, resulting in reduced tuber yield reaching $20 \%$ (19). Disease severity can be especially severe in poorly nourished crops due to insufficient nitrogen fertilization (23). Early blight control depends primarily on multiple fungicide applications in the Midwestern United States, typically weekly applications on long-season potato cultivars (e.g., Russet Burbank). A reduction in pesticide inputs, coupled with the use of effective reduced-risk chemistries, is a desirable goal for commercial potato production, particularly in regions where environmental factors (e.g., temperature,

Corresponding author: N. Rosenzweig

E-mail: rosen660@umn.edu

Accepted for publication 12 August 2007.

doi:10.1094/PDIS-92-4-0561

(C) 2008 The American Phytopathological Society relative humidity, and so on) favor disease development and consequent calendarbased applications. The quinone outside inhibitor (QoI) fungicides (kresoximmethyl, azoxystrobin, pyraclostrobin, trifloxystrobin, famoxadone, and fenamidone) offer a broad spectrum of activity, reduced environmental impact, and reduced toxicity to mammals compared with conventional materials used for the control of early blight on potato (e.g., chlorothalonil, mancozeb, and mefenoxam). The first QoI fungicides, kresoxim-methyl and azoxystrobin (AZ), were released commercially in Europe in the mid 1990s and the United States in the late 1990s $(1,11,12)$. QoI fungicides disrupt mitochondrial respiration by binding to cytochrome $b$. An experimental use permit (EUP) and, subsequently, a Section 18 registration were granted by the Environmental Protection Agency (EPA) that allowed potato growers in Wisconsin to use AZ (Quadris; Syngenta Crop Protection, Greensboro, NC) for control of A. solani midseason in 1998, and AZ received full label registration for commercial use on potato in 1999. Due to the persistent use of AZ and other QoI fungicides alternated with chlorothalonil $(\mathrm{CH})$ over the next six seasons after registration, the selection pressure for the development of QoI fungicide resistance imposed on $A$. solani was relatively high on potato crops in Wisconsin and other regions of potato production in the United States (20). In Wisconsin during 2001 to 2003, approximately $80 \%$ of the total potato acreage was treated with QoI fungicides (average of three applications per year) alternated with $\mathrm{CH}$ or EBDC materials (e.g., maneb, mancozeb, and metiram).

Resistance to AZ first was described in isolates of Blumeria graminis f. sp. tritici in commercial wheat fields in Europe after only 2 years of product use (20), when disease control efficacy declined in many of these sites. No difference was detected in aggressiveness between AZ-resistant and -sensitive $B$. graminis isolates $(5,25)$. Isolates resistant to QoI fungicides have been observed in other plant-pathogenic fungi at field and experimental sites after several years of intensive QoI use (2$5,10,14,17$ ) (http://www.frac.info/index). Fungicide efficacy studies in Wisconsin over seven seasons have shown that AZ product efficacy for the control of potato early blight declined after commercial release (21).

The mode of resistance at the molecular and genetic levels and the existence of mutants resistant to the QoI fungicides have been known for several years in several organisms (4), including the yeast Saccharomyces cerevisiae (6,7). In $S$. cerevisiae, resistance to QoI fungicides was attributed to point mutations in two regions of the cytochrome $b$ gene causing single amino acid changes in the Qo center coding region at amino acid positions from 127 to 147 and 275 to $296(8,11)$. A similar single-point mutation was observed when DNA sequences of the cytochrome $b$ were compared between QoI-sensitive and -resistant field isolates of several fungi $(3,13,17)$. An amino acid substitution at position 129 from phenylalanine $(\mathrm{F})$ to leucine (L) was observed in several plantpathogenic fungi, including $A$. solani, and was associated with a decreased sensitivity to QoI compounds $(3,13,17)$. Additionally, an amino acid substitution at position 143 from glycine $(G)$ to alanine $(A)$ rendered several species of plant-pathogenic fungi highly resistant to QoIs $(2,3,10,15)$. The F129L substitution caused reduced sensitivity to QoIs whereas the G143A substitution resulted in a complete loss of sensitiv- 
ity or a lack of response ("resistant") $(2,3,10,15)$. A. solani isolates with decreased in vitro sensitivity to AZ were detected in Wisconsin during 2001 from fungicide field experiments (21). During 2002 and 2003, a statewide monitoring of A. solani from commercial potato fields indicated an increase in frequency of recovery of isolates with reduced in vitro sensitivity to $\mathrm{AZ}$ and a wide distribution across the potato production regions of Wisconsin. This decrease in sensitivity was correlated with the presence of sitespecific mutations at position 129 of the cytochrome $b$ gene.

The effect of increased AZ applications coupled with practical fungicide resistance management tactics on experimental field populations of $A$. solani is not available in the literature. Disease pressure and the number of fungicide applications influence the evolution of fungicide resistance in many plant pathogens $(5,22,25)$. There is no single resistance management strategy that is applicable to every disease situation. Therefore, the design, testing, and implementation of effective fungicide resistance management strategies are important components of current integrated pest management programs for the control of potato early blight in Wisconsin.

Due to stringent EPA regulations on fungicide label registration and fungicide resistance management concerns, fungicide label recommendations emphasizing resistance management strategies are implemented from the time of initial registration. Therefore, comprehensive field experiments to evaluate potential fungicide resistance management strategies for $\mathrm{AZ}$ were initiated. The objective of this study was to determine the impact of potential resistance management strategies consisting of alternations and tank mixtures of AZ with $\mathrm{CH}$ in experimental field experiments on (i) early blight disease progress, (ii) the in vitro sensitivity to $\mathrm{AZ}$ in $A$. solani isolates recovered from experimental field plots, and (iii) the frequency of wild-type and mutant isolates of $A$. solani recovered from experimental field experiments.

\section{MATERIALS AND METHODS}

Prior to use of AZ by commercial potato growers and these studies, potato leaves infected with $A$. solani were collected from commercial growers' fields representing major production regions throughout Wisconsin to determine baseline sensitivity to AZ. Experimental field experiments were established at the Hancock Agricultural Research Station (HARS) and treatments were designed to evaluate any differences in foliar early blight progression and area under the disease progress curves (AUDPC) in the field. Subsequently, sensitivity of $A$. solani isolates to $\mathrm{AZ}$ was determined using an in vitro assay based on relative germination of conidia on fungicide-amended agar. Quantitative poly- merase chain reaction (Q-PCR) assays were employed to evaluate whether reduced sensitivity to $\mathrm{AZ}$ was correlated with site-specific mutations in the cytochrome $b$ gene, caused by singlenucleotide polymorphisms (SNPs).

Materials for in vitro sensitivity to AZ. Technical-grade AZ (95.3\% a.i.) was obtained from Syngenta Crop Protection. Bacto Agar was from Difco Laboratories (Detroit). All other chemicals were from Sigma-Aldrich (St. Louis) unless otherwise noted.

Field experiments. Annual field experiments were established to evaluate the effects of alternations and tank mixtures of AZ (Q = Quadris 2.08 F; Syngenta Crop Protection; AZ, 0.46 liters/ha) with $\mathrm{CH}$ $(\mathrm{BZ}=$ Bravo Zn 4.17 F; Syngenta Crop Protection; $\mathrm{CH}+$ zinc, 2.5 liters/ha) and Bravo WS (BW; Syngenta Crop Protection; $\mathrm{CH}+$ weather stick, 1.8 liters/ha) for early blight control. Plots were planted between 23 and 29 April from 2001 to 2003 at the HARS in central Wisconsin. Fungicide treatments consisted of 0 to 6 applications of AZ out of a total of 10 applications during the growing season (Table 1). Certified Russet Burbank US\#1 seed tubers (Wisconsin Seed Potato Certification) were mechanically cut into approximately 62-g seed pieces and allowed to heal prior to planting. A randomized complete block design with four replications was used for the experiments, with each plot consisting of four 7-m-long rows spaced $1 \mathrm{~m}$ apart, with tubers placed $38 \mathrm{~cm}$ apart in the row. Drive rows for pesticide application were placed in adjacent plots within field experiments to avoid soil compaction and provide a source for inoculum for dispersal of A. solani. Fungicide treatments were applied to all four rows of each plot at weekly intervals starting between 19 and 26 June and ending between 20 August and 4 September, depending on planting dates, for a total of 10 weeks (Table 1). Treatments were applied in a volume equivalent to 327 liters of water/ha at $276 \mathrm{kPa}$, using Tee Jet hollow disc cone D3-23 nozzles (15 nozzles at 20$\mathrm{cm}$ spacing) with a tractor-mounted boom sprayer pressurized with an air compressor. Plots were not inoculated but relied on natural sources of $A$. solani for disease establishment. Disease severity was assessed weekly on four arbitrarily selected plants per row from 19 June through 4 September using the Horsfall-Barratt rating scale of 0 (no infection) to 11 (all foliage and stems dead) and converted to percent. Rainfall was measured during the growing season and an additional 30 to 70 $\mathrm{cm}$ of water was applied as needed via overhead sprinkler irrigation in 24 to 40 applications over the 3 years (27 May to 13 September), 2001 to 2003.

Sampling procedure. AZ first was used in commercial fields in Wisconsin during 1998 in a tightly controlled EUP program.
A. solani collected from fields prior to the application of $\mathrm{AZ}$ constituted the baseline isolates and were screened in a previous study (22). The in vitro fungicide sensitivity of fungal isolates was investigated in the laboratory. During 2001, 2002, and 2003, 20 potato leaves infected with $A$. solani were collected randomly in a standard $\mathrm{W}$ pattern from fungicide trial plots at HARS near the end of the growing season. Treatment plots (four replicates) received up to six applications per season of Quadris in 2001 and 2002, and up to three applications in 2003 (Table 1). Treatments, as described previously, were tested to identify potential differences in foliar early blight progression and AUDPC in the field. Mean effective concentration of AZ (mg/liter) needed for $50 \%$ inhibition of spore germination $\left(\mathrm{EC}_{50}\right)$ of $A$. solani collected in the treated plots (four replicates) then was determined in the laboratory using individual monoconidial isolates of A. solani (394 isolates total).

From each leaf, one lesion was cut with a cork borer; the lesions were chosen visually from similar sizes and in similar stages of sporulation. All leaf disks derived from a particular fungicide treatment plot were placed onto water agar media (WA) amended with streptomycin for sporulation induction and positive identification (24). One conidium of $A$. solani from each sporulating lesion was transferred to clarified V8 (CV8) amended with $\mathrm{CaCO}_{3}$ agar (100 ml of CV8, $900 \mathrm{ml}$ of distilled $\mathrm{H}_{2} \mathrm{O}$, $15 \mathrm{~g}$ of Bacto Agar, and $1.5 \mathrm{~g}$ of $\mathrm{CaCO}_{3}$ ) in 100 -mm petri plates, placed under fluorescent light with a $24-\mathrm{h}$ photoperiod at $20^{\circ} \mathrm{C}$ for 10 to 14 days, and subsequently stored at $-20^{\circ} \mathrm{C}$ on colonized filter paper to reduce effects of subculturing and for further analyses.

In vitro assay of isolate sensitivity to $\mathbf{A Z}$ fungicide. An in vitro assay was developed based on relative conidial germination on AZ-amended media. Sensitivity of germinating conidia to $\mathrm{AZ}$, derived from monoconidial isolates, was determined for isolates collected from the baseline sample and experimental field trial locations described above. Sensitivity of germinating conidia was assessed on WA $(1,000 \mathrm{ml}$ of distilled $\mathrm{H}_{2} \mathrm{O}$ and $10 \mathrm{~g}$ of Bacto Agar) amended with AZ. AZ (a.i.) was dissolved in acetone and added to the WA at concentrations of $0.00,0.001,0.01,0.1,1$, and 10 $\mathrm{mg} /$ liter. Additionally, salicylhydroxamic acid (SHAM) dissolved in methanol was added to the WA at $100 \mathrm{mg} / \mathrm{liter}$. SHAM inhibits the alternative oxidase (AOX) pathway that has been suggested as a possible mode of QoI resistance in vitro in other fungi (31). Control medium included equal concentrations of acetone and methanol as fungicide-amended WA.

A hemacytometer was used to adjust the conidial suspension to $1 \times 10^{4}$ conidia per $\mathrm{ml}$, and a $50-\mu \mathrm{l}$ aliquant was spread on the surface of AZ alone or AZ + SHAM- 
amended media. Germination of 50 conidia was assessed at each concentration (two replications) after incubation under continuous light for $4 \mathrm{~h}$ at $26^{\circ} \mathrm{C}$. A conidium was rated as germinated if a normally developing germ tube was at least equal to the total length of a conidium (beak and tail), if an appressorium formed at the tip of the germ tube, or if multiple germ tubes developed. Isolate sensitivities were expressed as relative germination (RG) (16), which is defined as the ratio of conidia germinating in the presence of $\mathrm{AZ}$ to those germinating in the absence of $A Z$ $\times 100 \%$. Isolate sensitivity expressed in $\mathrm{mg} / \mathrm{liter}$ was determined by the $\mathrm{EC}_{50}$. $\mathrm{EC}_{50}$ values were determined by interpolation of the $50 \%$ intercept, based on regression of the arcsine of RG on the $\log _{10}$-transformed fungicide concentration.

SNP detection assay. A SNP detection assay using a Q-PCR procedure was employed to evaluate whether shifts in sensi- tivity of A. solani isolates to AZ were correlated with an SNP in the cytochrome $b$ gene. Genomic DNA extractions from plant (herbarium specimens) and fungal material (10- to 12-day-old cultures) was prepared using either DNeasy Plant Minikit (Qiagen, Valencia, CA) or Bio101
Fast DNA Kit (Qbiogene, Carlsbad, CA) according to the manufacturers' protocols. A subsample of A. solani isolates (160 isolates total) collected from fungicide field experiments was used in the SNP detection assay. Genomic DNA, conidia, or mycelia were stored on dry ice and sent

Table 2. Primers and fluorescent-labeled probes used in a real-time polymerase chain reaction assay to detect single-nucleotide polymorphisms in the cytochrome $b$ gene of Alternaria solani ${ }^{\mathrm{z}}$

\begin{tabular}{ll}
\hline Primers, probes & \multicolumn{1}{c}{ Sequence $\left(\mathbf{5}^{\prime}\right.$ to $\left.\mathbf{3}^{\prime}\right)$} \\
\hline 129 Forward primer & GAACTATTGGTACTGTTATCTTTATCTTAATGATG \\
129 Reverse primer & AAGACATTTGCCCATAAGGAAGAA \\
143 Forward primer & GTATGTTCTTCCTTATGGGCAAATG \\
143 Reverse primer & CTCACTTTGTTTATGTTATTTAACCAAGAATG \\
129 WT probe & [FAM] TACAGCTTTCCTGGGTTA \\
129 MUT1 probe & [VIC] TACAGCTCTCCTGGGTT \\
129 MUT2 probe & [VIC] TACAGCTTTACTGGGTTAT \\
129 MUT3 probe & [VIC] TACAGCTTTGCTGGGTT \\
143 WT probe & [FAM] TCTTTATGAGGTAATTT \\
143 MUT probe & [VIC] TCTTTATGAAGCTAAATTT- \\
\hline
\end{tabular}

z Sequences from Syngenta International Patent WO02081742.

Table 1. Collection year, applied fungicides, application history, area under the disease progress curve (AUDPC), mean effective concentration of azoxystrobin (AZ) needed for $50 \%$ inhibition of spore germination $\left(\mathrm{EC}_{50}\right)$, and mutations in the cytochrome $b$ gene in isolates of Alternaria solani recovered from fungicide field experiments at Hancock Agricultural Research Station during 2001, 2002, and 2003

\begin{tabular}{|c|c|c|c|c|c|c|c|c|c|}
\hline \multirow[b]{2}{*}{ Year, treatment ${ }^{\mathrm{v}}$} & \multirow[b]{2}{*}{ Quadris (weeks)w } & \multirow[b]{2}{*}{ QoI $^{x}$} & \multirow[b]{2}{*}{ AUDPC $^{\mathbf{y}}$} & \multirow[b]{2}{*}{ No. of isolates } & \multirow[b]{2}{*}{ Mean EC E0 $_{50}(\mathrm{mg} / \text { /iter })^{\mathrm{z}}$} & \multirow{2}{*}{$\frac{\text { Wild type }^{\mathrm{t}}}{\text { TTC }}$} & \multicolumn{3}{|c|}{ Mutant type $^{u}$} \\
\hline & & & & & & & TTA & CTC & TTG \\
\hline \multicolumn{10}{|l|}{2001} \\
\hline Untreated & N/A & 0 & $0.243 \mathrm{a}$ & 20 & $0.27 \mathrm{c}$ & 4 & 3 & 0 & 1 \\
\hline $\mathrm{BZ}$ & N/A & 0 & $0.149 \mathrm{~b}$ & 20 & $0.22 \mathrm{c}$ & 9 & 1 & 0 & 0 \\
\hline $\mathrm{Q} / \mathrm{BZ}$ & 1 & 1 & $0.05 \mathrm{c}$ & 20 & $0.47 \mathrm{bc}$ & 1 & 5 & 1 & 0 \\
\hline $\mathrm{Q} / \mathrm{BZ}$ & $1 \& 3$ & 2 & $0.084 \mathrm{c}$ & 20 & $1.01 \mathrm{bc}$ & 1 & 6 & 1 & 0 \\
\hline $\mathrm{Q} / \mathrm{BZ}$ & $1,3 \& 5$ & 3 & $0.047 \mathrm{c}$ & 20 & $0.47 \mathrm{bc}$ & 0 & 7 & 0 & 0 \\
\hline $\mathrm{Q} / \mathrm{BZ}$ & $1,3,5 \& 7$ & 4 & $0.055 \mathrm{c}$ & 20 & $0.53 \mathrm{bc}$ & 0 & 4 & 2 & 1 \\
\hline $\mathrm{Q} / \mathrm{BZ}$ & $1,3,5,7 \& 8$ & 5 & $0.049 \mathrm{c}$ & 20 & $2.39 \mathrm{a}$ & 0 & 7 & 2 & 0 \\
\hline $\mathrm{Q} / \mathrm{BZ}$ & $1,3,5,7-9$ & 6 & $0.059 \mathrm{c}$ & 20 & $1.26 \mathrm{~b}$ & 0 & 9 & 2 & 0 \\
\hline$P$ value & $\ldots$ & $\ldots$ & $<0.0001$ & $\ldots$ & $<0.0001$ & $\ldots$ & $\ldots$ & $\ldots$ & $\ldots$ \\
\hline LSD & $\ldots$ & $\ldots$ & 0.0397 & $\ldots$ & 1.976 & $\ldots$ & $\ldots$ & $\ldots$ & $\ldots$ \\
\hline \multicolumn{10}{|l|}{2002} \\
\hline Untreated & N/A & 0 & 0.07 & 20 & $0.54 \mathrm{bc}$ & 4 & 1 & 0 & 1 \\
\hline $\mathrm{BZ}$ & N/A & 0 & 0.038 & 20 & $0.48 \mathrm{bcd}$ & 0 & 3 & 0 & 4 \\
\hline $\mathrm{Q} / \mathrm{BZ}$ & 1 & 1 & 0.039 & 20 & $0.83 \mathrm{a}$ & 0 & 6 & 1 & 1 \\
\hline $\mathrm{Q} / \mathrm{BZ}$ & $1 \& 3$ & 2 & 0.029 & 20 & $0.72 \mathrm{ab}$ & 0 & 4 & 0 & 4 \\
\hline $\mathrm{Q} / \mathrm{BZ}$ & $1,3 \& 5$ & 3 & 0.056 & 20 & $0.43 \mathrm{~cd}$ & 0 & 8 & 0 & 2 \\
\hline $\mathrm{Q} / \mathrm{BZ}$ & $1,3,5 \& 7$ & 4 & 0.041 & 20 & $0.56 \mathrm{bc}$ & 0 & 6 & 1 & 3 \\
\hline $\mathrm{Q} / \mathrm{BZ}$ & $1,3,5,7 \& 8$ & 5 & 0.032 & 20 & $0.64 \mathrm{abc}$ & 0 & 4 & 2 & 2 \\
\hline $\mathrm{Q} / \mathrm{BZ}$ & $1,3,5,7-9$ & 6 & 0.038 & 20 & $0.66 \mathrm{abc}$ & 0 & 7 & 0 & 1 \\
\hline $\mathrm{Q}+\mathrm{BW} / \mathrm{BW}$ & $1,3 \& 5$ & 3 & 0.026 & 10 & $0.28 \mathrm{~d}$ & 0 & 6 & 0 & 3 \\
\hline$P$ value & $\ldots$ & $\ldots$ & 0.1313 & $\ldots$ & 0.0002 & $\ldots$ & $\ldots$ & $\ldots$ & $\ldots$ \\
\hline LSD & $\ldots$ & $\ldots$ & N/A & $\ldots$ & 1.975 & $\ldots$ & $\ldots$ & $\ldots$ & $\ldots$ \\
\hline \multicolumn{10}{|l|}{2003} \\
\hline Untreated & N/A & 0 & $0.292 \mathrm{a}$ & 11 & 0.53 & 0 & 2 & 1 & 0 \\
\hline BZ & N/A & 0 & $0.208 \mathrm{bc}$ & 6 & 0.54 & 1 & 1 & 1 & 0 \\
\hline $\mathrm{Q} / \mathrm{BZ}$ & 1 & 1 & $0.265 \mathrm{ab}$ & 11 & 0.81 & 1 & 3 & 0 & 0 \\
\hline $\mathrm{Q} / \mathrm{BZ}$ & $1 \& 3$ & 2 & $0.223 \mathrm{bc}$ & 11 & 0.9 & 0 & 1 & 0 & 3 \\
\hline $\mathrm{Q} / \mathrm{BZ}$ & $1,3 \& 5$ & 3 & $0.217 \mathrm{bc}$ & 13 & 0.5 & 0 & 0 & 0 & 2 \\
\hline $\mathrm{Q}+\mathrm{BW} / \mathrm{BW}$ & $1,3 \& 5$ & 3 & $0.17 \mathrm{c}$ & 12 & 0.78 & 2 & 1 & 0 & 0 \\
\hline$P$ value & $\ldots$ & $\ldots$ & 0.0135 & $\ldots$ & 0.094 & $\ldots$ & $\ldots$ & $\ldots$ & $\ldots$ \\
\hline LSD & $\ldots$ & $\ldots$ & 0.0651 & $\ldots$ & N/A & $\ldots$ & $\ldots$ & $\ldots$ & $\ldots$ \\
\hline
\end{tabular}

${ }^{t}$ A subsample of isolates was screened in the single-nucleotide polymorphism detection assay. Wild-type isolates are considered sensitive to AZ and constituted the 1998 baseline for this study. Sequencing of the cytochrome $b$ gene revealed a phenylalanine at amino acid position 129 of the transcribed protein.

"Mutant-type isolates have a decreased sensitive to AZ and the frequency of their recovery increased after commercial release of quinone outside inhibitor (QoI) fungicides. Sequencing of the cytochrome $b$ gene revealed a leucine at amino acid position 129 of the transcribed protein.

${ }^{\mathrm{v}}$ Treatment chemicals include $\mathrm{Q}=$ Quadris $2.08 \mathrm{~F}$ (AZ, 0.46 liters/ha), BZ = Bravo Zn $4.17 \mathrm{~F}$ (chlorothalonil + zinc, 2.5 liters/ha), and BW = Bravo WS (chlorothalonil + weather stick, 1.8 liters/ha).

${ }^{w}$ Weeks that Quadris was applied. In the remaining weeks, Bravo Zn or Bravo WS was applied; N/A = not applicable.

$x$ Number of QoI applications per season.

${ }^{y}$ Relative AUDPC based on the assessments of disease severity. Values were divided by the number of days in the season and expressed as a proportion of the maximum observed AUDPC. Values followed by the same letter are significantly different, based on Fisher's protected least significant difference (LSD) test; N/A = not applicable.

z Values followed by the same letter are significantly different, based on Fisher's protected LSD test; N/A = not applicable. 
to Syngenta, Vero Beach, FL or Jealott's Hill, UK for SNP detection assays. tion (GCT to GGT) whereas three different SNPs can cause the F129L substitution (TTC to TTA, CTC, and TTG). Primers and fluorescent-labeled minor-groovebinding probes, to be used in a real-time PCR assay (Table 2), were designed for the detection of the four SNPs responsible for the G143A and F129L amino acid substitutions in $A$. solani (International Patent Publication No. WO02081742). Each hybridization reaction consisted of $5 \mu \mathrm{l}$ of template DNA, $2 \times$ TaqMan mastermix (Applied Biosystems Inc., Foster City, CA), $18 \mu \mathrm{M}$ forward and reverse primer, and $2 \mu \mathrm{M}$ wild-type and mutant probe in a real-time PCR instrument (Applied Biosystems Inc.) was used in the SNP detection assays on site at Syngenta, Vero Beach, FL. Amplifications were run with the following thermal-cycler parameters: $50^{\circ} \mathrm{C}$ for $2 \mathrm{~min}, 95^{\circ} \mathrm{C}$ for $10 \mathrm{~min}, 35$ cycles of $92^{\circ} \mathrm{C}$ for $15 \mathrm{~s}$, and $60^{\circ} \mathrm{C}$ for $1 \mathrm{~min}$. Data were collected during the $60^{\circ} \mathrm{C}$ step with 5-carboxy-X-rhodamine (ROX) as the reference standard.
One SNP can cause the G143A substitu25- $\mu$ l reaction volume. An ABI prism 7700

Data analysis. Disease severity ratings were converted to percentages using midpoints of Horsfall-Barratt class intervals. Data for each observation date was plotted on a graph (disease severity versus time) and AUDPC was calculated for each treatment providing a measure of the relative severity of disease throughout the season. A disease rating of $100 \%$ severity for the entire season would produce a maximum possible AUDPC value of $100 \%$ $\times \mathrm{N}$, where $\mathrm{N}=$ the number of days in the season. Dividing the actual AUDPC values by this maximum possible value would result in the relative AUDPC; on a scale of 0 to 1.0 , a disease rating of $100 \%$ severity for AUDPC value of 1.0 represents the maximum possible relative AUDPC. All relative AUDPC values are expressed as a proportion of this value and were compared using one-way analysis of variance (ANOVA), and Fisher's protected least significant difference (LSD) procedure was used for mean separation.

$\log _{10}$-transformed mean $\mathrm{EC}_{50}$ values were compared using one-way ANOVA and Fisher's protected LSD procedure for mean separation. Frequencies of recovery of each of the mutant types were com-
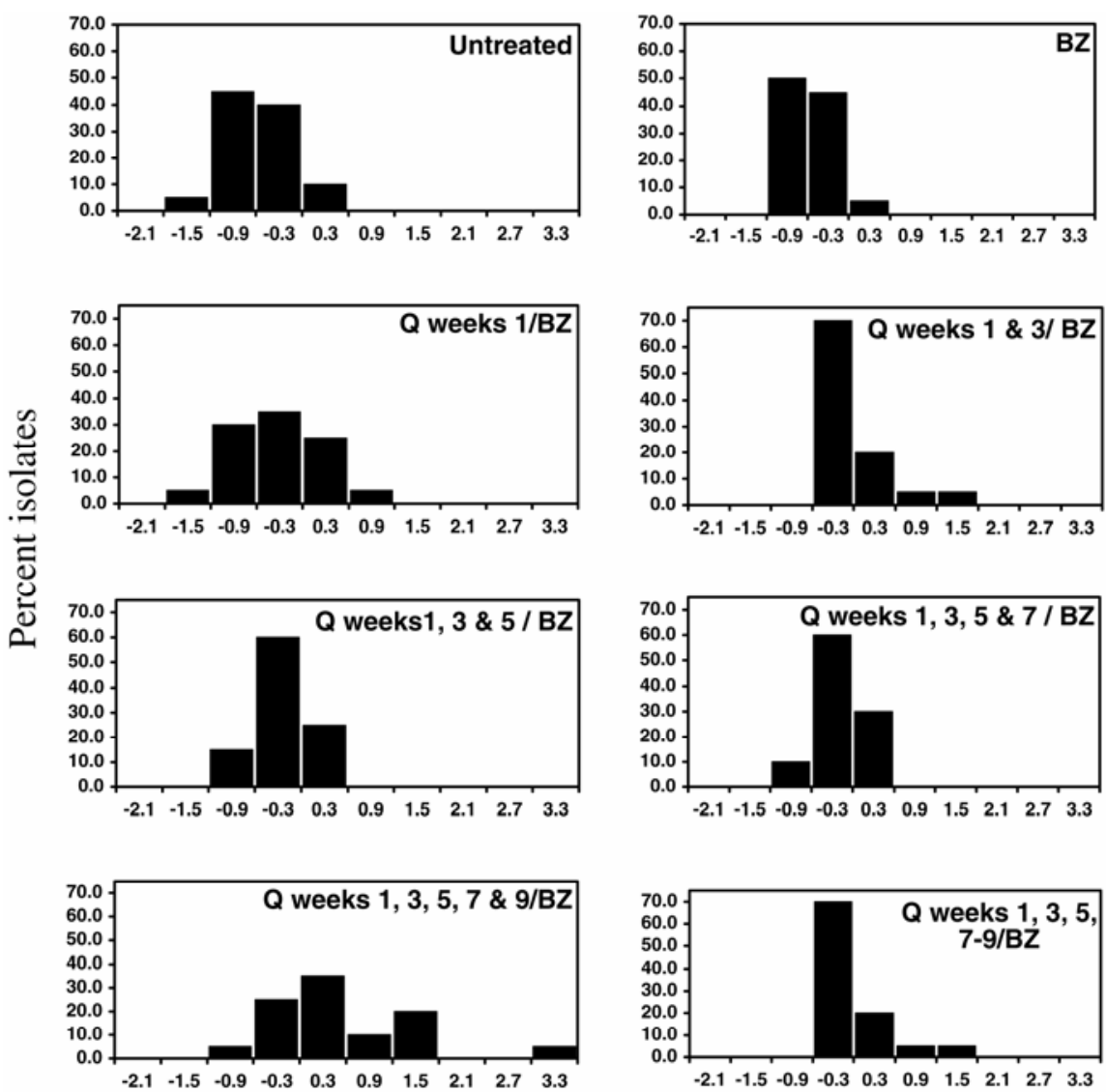

$$
\log _{10} \mathrm{EC}_{50}
$$

Fig. 1. Frequency distributions of in vitro sensitivity to azoxystrobin (AZ) of Alternaria solani isolates collected in 2001 from potato leaves exposed to different fungicide treatments in the field. Sensitivity expressed as the $\log _{10}$-transformed concentration of AZ needed for $50 \%$ inhibition of spore germination $\left(\mathrm{EC}_{50}, \mathrm{mg} / \mathrm{liter}\right)$ based on an in vitro conidia germination assay on medium amended with $\mathrm{AZ}$ and salicylhydroxamic acid. $\mathrm{Q}=$ Quadris $(\mathrm{AZ})$ and $\mathrm{BZ}=$ Bravo $\mathrm{Zn}$ (chlorothalonil + zinc). pared, using a $\chi^{2}$ test, to assess for potential differences among treatments. All statistical analyses were performed with Minitab (v.10.5 Xtra Power; Minitab Inc., State College, PA) or SAS (v.8.0; SAS Institute Inc., Cary, NC). Real-time PCR assay results were analyzed using SDS software (v.1.7; Applied Biosystems Inc.).

\section{RESULTS}

Field experiments. Final disease severity in untreated plots was $88.7,81.3$, and $84.6 \%$ during 2001, 2002, and 2003, respectively. During 2001, AUDPC values from treatments with one to six applications of $\mathrm{AZ}$ were significantly lower than the untreated control and $\mathrm{CH}$ alone, but were not significantly different from one another (Table 1). During 2002, there were no significant differences in AUDPC values among treatments (Table 1). Fungicide treatments with multiple applications of AZ did not provide additional disease control; therefore, treatments with more than three AZ applications were eliminated in 2003. During 2003, AUDPC values from all fungicide treatments, except for the treatment with one application of AZ, were significantly lower than the untreated control. Furthermore, the AUDPC for all tested alternations, including the tank mix of $\mathrm{AZ}$ and $\mathrm{CH}$, were not significantly different from those plots treated with $\mathrm{CH}$ alone (Table 1).

In vitro assay of isolate sensitivity to $\mathrm{AZ}$ fungicide. $\mathrm{EC}_{50}$ values representing in vitro sensitivity of baseline $A$. solani isolates to $\mathrm{AZ}$ ranged from 0.012 to 0.997 $\mathrm{mg} /$ liter to AZ without SHAM. Sensitivity of baseline isolates in the presence of SHAM ranged from 0.008 to $0.069 \mathrm{mg} / \mathrm{liter}$ for $\mathrm{AZ}$. A wide range of $\mathrm{EC}_{50}$ values was observed for $A$. solani, with a mean sensitivity of $0.179 \mathrm{mg} / \mathrm{liter}$ (standard deviation $[\mathrm{SD}]=0.088)$ for $\mathrm{AZ}$ alone. Mean sensitivity $\left(\mathrm{EC}_{50}\right)$ of baseline isolates in the presence of $\mathrm{AZ}$ and SHAM was significantly lower, $0.031 \mathrm{mg} / \mathrm{liter}(\mathrm{SD}=0.1)$ and was less variable than for $\mathrm{AZ}$ alone.

$\mathrm{EC}_{50}$ values of isolates collected from fungicide field experiments in 2001, 2002, and 2003 were significantly higher than those of the baseline isolates $(P<0.0001$, data not shown). Mean $\mathrm{EC}_{50}$ values for isolates collected in 2001 from plots treated with one to four applications of $\mathrm{AZ}$ were not significantly different from those of isolates from the untreated control plots and plots treated with $\mathrm{CH}$ alone (Fig. 1; Table 1). Mean $\mathrm{EC}_{50}$ values from treatments with five or six applications of $\mathrm{AZ}$ were significantly higher compared with the untreated control plots or from plots treated with $\mathrm{CH}$ alone, but there was no difference in mean $\mathrm{EC}_{50}$ among isolates from plots treated with one, two, three, four, and six applications of AZ (Fig. 1; Table 1).

Mean $\mathrm{EC}_{50}$ values of $A$. solani isolates collected in 2002 from plots treated with 
two to six applications of $\mathrm{AZ}$ were not significantly different from the untreated control and $\mathrm{CH}$ alone (Fig. 1; Table 2). Mean $\mathrm{EC}_{50}$ values from plots treated with one application of $\mathrm{AZ}$ and tank mixtures of $\mathrm{AZ}$ or $\mathrm{CH}$ were significantly different from each other, and the latter was lower than the mean $\mathrm{EC}_{50}$ of isolates from the untreated control and from those treated with $\mathrm{CH}$ alone (Fig. 2; Table 1). Mean sensitivity in vitro of isolates from plots treated with three applications of $\mathrm{AZ}$ was significantly different from treatments consisting of one, two, four, five, and six applications of $\mathrm{AZ}$, but was not different from mean $\mathrm{EC}_{50}$ of isolates from plots treated with three tank-mixed applications of AZ during 2002 (Fig. 2; Table 1). Several treatments that included three applications of $\mathrm{AZ}$ in prepack and tank mixtures at various rates alternated with $\mathrm{CH}$ were tested only in 2002 (data not shown). The application of a prepack mixture of $\mathrm{AZ}$ and $\mathrm{CH}$ at a low rate (1.4 liters/ha) resulted in a wider range of sensitivities to $\mathrm{AZ}$ and a significantly lower mean $\mathrm{EC}_{50}$ than all other tested mixtures in 2002, but the mean sensitivity was not significantly different from those isolates from plots treated with one to six applications of AZ $(P=0.05$, data not shown). Fungicide field experiments in 2003 revealed no statistical difference in mean $\mathrm{EC}_{50}$ values among treatments (Fig. 3; Table 1).

SNP detection assay. All of the isolates collected in 1998 were wild type at amino acid positions 129 (F; codon TTC) and 143 (G; codon GGT). All of the isolates collected throughout the course of this study were wild type at position 143 , whereas all three possible SNP combinations (TTA, CTC, and TTG) were detected at position 129 from the recovered $A$. solani isolates from field experiments in 2001, 2002, and 2003 (Table 1). The majority of the 2001 (77\%), 2002 (95\%), and 2003 (79\%) isolates carried an SNP mutation. The most common mutant type recovered in 2001 was TTA followed by CTC and TTG (Ta- ble 1). The most common mutant type recovered in 2002 and 2003 was TTA followed by TTG and CTC (Table 1).

The results from the molecular assays indicated that there were significant differences in the frequency of mutant types detected between isolates from the untreated control and plots treated with three to six applications of $\mathrm{AZ}$, and between all
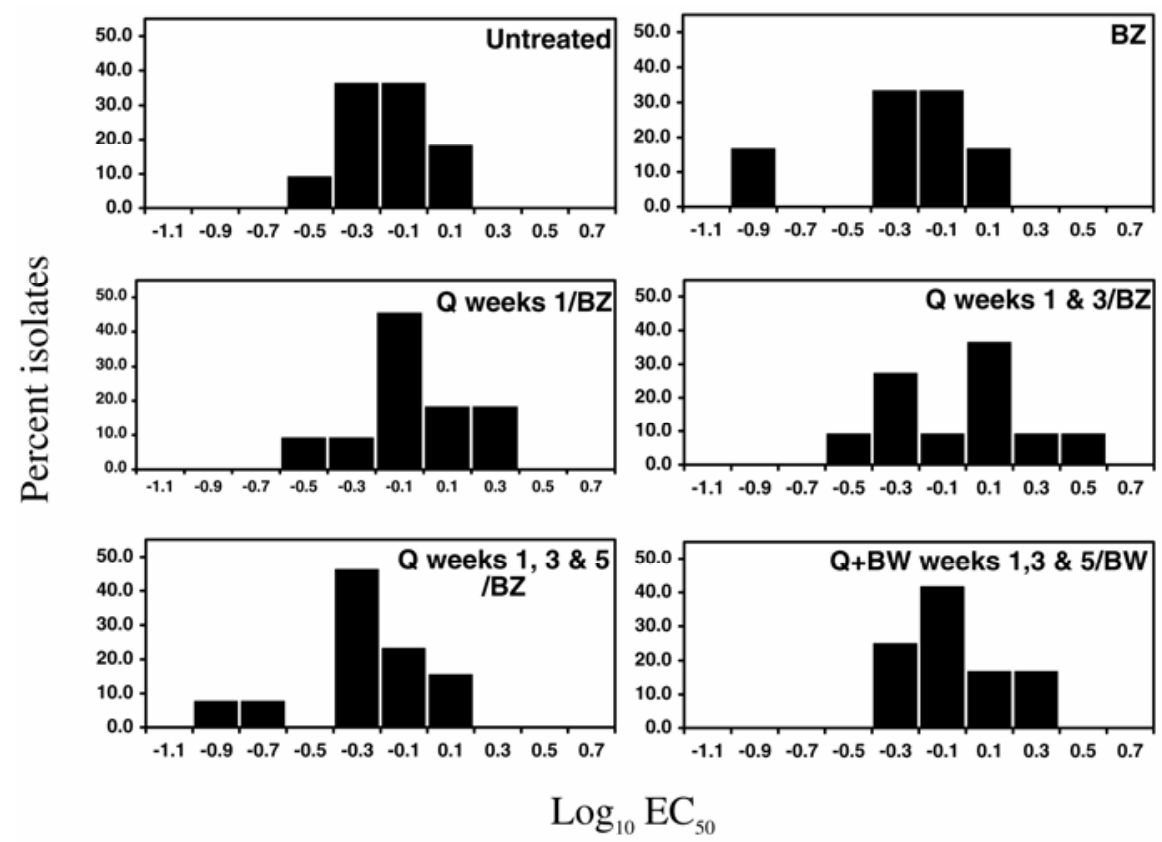

Fig. 3. Frequency distributions of in vitro sensitivity to azoxystrobin (AZ) of Alternaria solani isolates collected in 2002 from potato leaves exposed to different fungicide treatments in the field. Sensitivity expressed as the $\log _{10}$-transformed concentration of $\mathrm{AZ}$ needed for $50 \%$ inhibition of spore germination $\left(\mathrm{EC}_{50}, \mathrm{mg} / \mathrm{liter}\right)$ based on an in vitro conidia germination assay on medium amended with $\mathrm{AZ}$ and salicylhydroxamic acid. $\mathrm{Q}=$ Quadris $(\mathrm{AZ})$ and $\mathrm{BZ}=$ Bravo $\mathrm{Zn}$ (chlorothalonil + zinc) $\mathrm{BW}=$ Bravo WS (chlorothalonil).
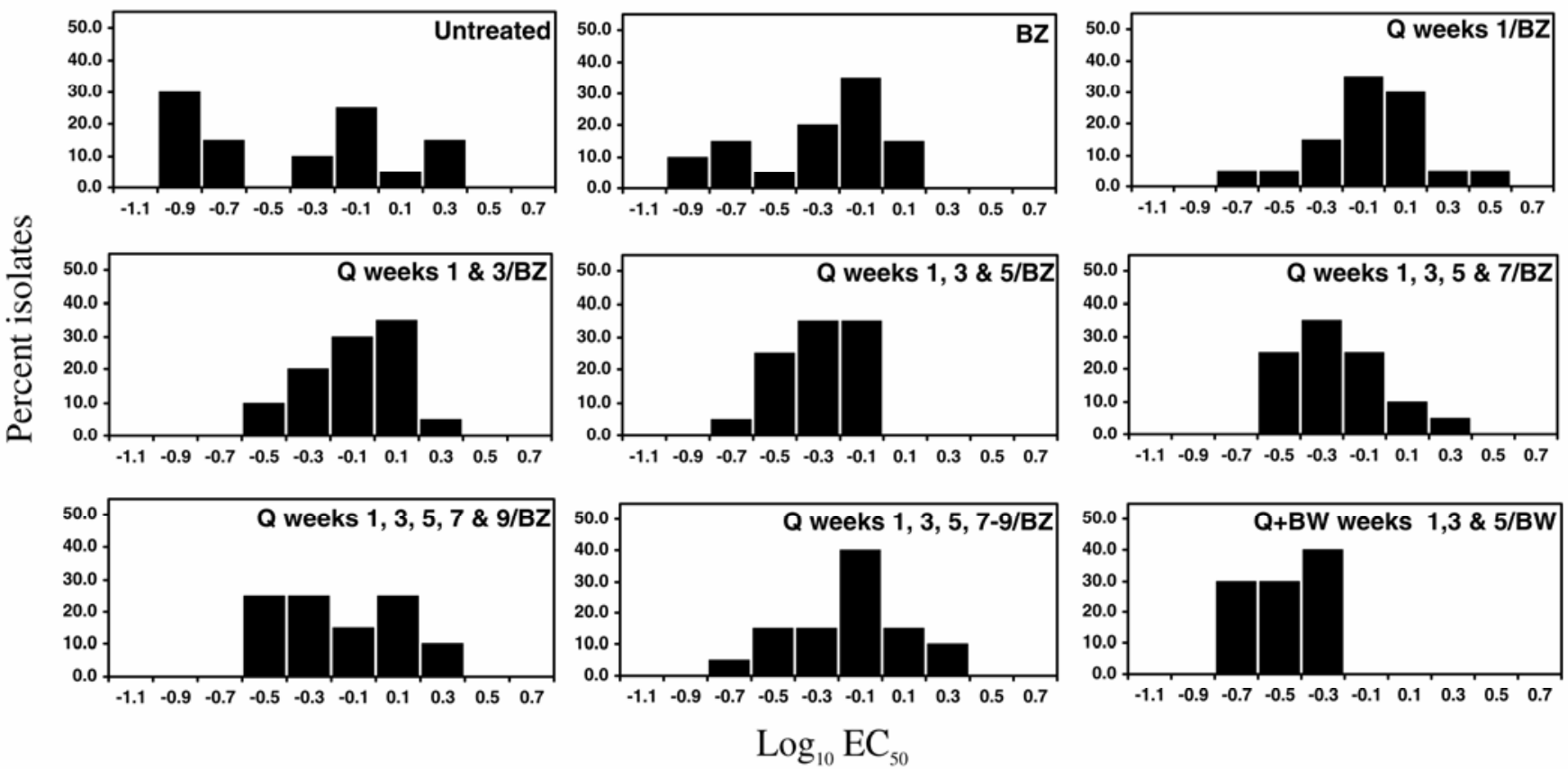

Fig. 2. Frequency distributions of in vitro sensitivity to azoxystrobin (AZ) of Alternaria solani isolates collected in 2002 from potato leaves exposed to different fungicide treatments in the field. Sensitivity expressed as the $\log _{10}$-transformed concentration of AZ needed for $50 \%$ inhibition of spore germination $\left(\mathrm{EC}_{50}, \mathrm{mg} /\right.$ liter $)$ based on an in vitro conidia germination assay on medium amended with $\mathrm{AZ}$ and salicylhydroxamic acid. $\mathrm{Q}=\mathrm{Quadris}(\mathrm{AZ})$ and $\mathrm{BZ}=\mathrm{Bravo}$ Zn (chlorothalonil + zinc) BW = Bravo WS (chlorothalonil). 
tested alternations and $\mathrm{CH}$ alone in 2001 (Tables 1 and 3). There was no difference in the frequency of recovered mutant types detected among tested alternations of one to six applications of AZ in 2001. In 2002, frequencies of mutant types recovered from all tested fungicide treatments were significantly different from the untreated control (Tables 1 and 3). Conversely, there were no significantly significant differences in frequency of mutants among all fungicide treatments (Tables 1 and 3). In 2003 , there was no difference in the frequency of recovered mutant types detected among all tested fungicide treatments (Table 1).

\section{DISCUSSION}

This project was designed to develop information needed to augment current disease and crop management systems, with a focus on testing existing resistance management strategies for the control of potato early blight in Wisconsin. Results based on data collected during 2001 indicated that one to three applications of AZ alternated with $\mathrm{CH}$ in a 9-week application program gave the best early blight control. Moreover, growers have observed a boost in tuber yield when three applications of $\mathrm{AZ}$ were included in their management program (W. R. Stevenson, unpublished). During 2002, there was greater variability in disease severity among replications and less disease, possibly due to environmental conditions unfavorable for disease occurrence and pathogen spread. During 2003,

Table 3. Comparisons of frequency of wild-type and mutant isolates characterized by the amino acid substitution F129L in isolates of Alternaria solani recovered from potato leaves exposed to different fungicide treatments in field experiments in 2001 and $2002^{\mathrm{y}}$

\begin{tabular}{cccccccccc}
\hline Treatment $^{\mathbf{z}}$ & $\mathbf{1}$ & $\mathbf{2}$ & $\mathbf{3}$ & $\mathbf{4}$ & $\mathbf{5}$ & $\mathbf{6}$ & $\mathbf{7}$ & $\mathbf{8}$ & $\mathbf{9}$ \\
\hline 2001 & & & & & & & & & \\
1 & $\ldots$ & - & - & - & + & + & + & + & $\ldots$ \\
2 & $\ldots$ & $\ldots$ & + & + & + & + & + & + & $\ldots$ \\
3 & $\ldots$ & $\ldots$ & $\ldots$ & - & - & - & - & - & $\ldots$ \\
4 & $\ldots$ & $\ldots$ & $\ldots$ & $\ldots$ & - & - & - & - & $\ldots$ \\
5 & $\ldots$ & $\ldots$ & $\ldots$ & $\ldots$ & $\ldots$ & - & - & - & $\ldots$ \\
6 & $\ldots$ & $\ldots$ & $\ldots$ & $\ldots$ & $\ldots$ & $\ldots$ & - & - & $\ldots$ \\
7 & $\ldots$ & $\ldots$ & $\ldots$ & $\ldots$ & $\ldots$ & $\ldots$ & $\ldots$ & - & $\ldots$ \\
8 & $\ldots$ & $\ldots$ & $\ldots$ & $\ldots$ & $\ldots$ & $\ldots$ & $\ldots$ & $\ldots$ & $\ldots$ \\
2002 & $\ldots$ & + & + & + & + & + & + & + & + \\
1 & $\ldots$ & $\ldots$ & - & - & - & - & - & - & - \\
2 & $\ldots$ & $\ldots$ & $\ldots$ & - & - & - & - & - & - \\
3 & $\ldots$ & $\ldots$ & $\ldots$ & $\ldots$ & - & - & - & - & - \\
4 & $\ldots$ & $\ldots$ & $\ldots$ & $\ldots$ & - & - & - & - & - \\
5 & $\ldots$ & $\ldots$ & $\ldots$ & $\ldots$ & $\ldots$ & - & - & - & - \\
6 & $\ldots$ & $\ldots$ & $\ldots$ & $\ldots$ & $\ldots$ & $\ldots$ & - & - & - \\
7 & $\ldots$ & $\ldots$ & $\ldots$ & $\ldots$ & $\ldots$ & $\ldots$ & $\ldots$ & $\ldots$ & - \\
8 & $\ldots$ & $\ldots$ & $\ldots$ & $\ldots$ & & & - \\
9 & $\ldots$ & $\ldots$ & $\ldots$ & $\ldots$ & & & & \\
\hline
\end{tabular}

${ }^{y}$ Symbols: + indicates a significant difference between treatments using $\chi^{2}$ analysis $(\alpha=0.05)$ and indicates no difference. No significant differences in frequency of recovered isolates among treatments were detected in 2003.

${ }^{\mathrm{z}}$ Treatment chemicals include $\mathrm{Q}=$ Quadris $2.08 \mathrm{~F}$ (azoxystrobin, 0.46 liters/ha), BZ = Bravo Zn 4.17 $\mathrm{F}$ (chlorothalonil + zinc, 2.5 liters/ha), and BW = Bravo WS (chlorothalonil + weather stick, 1.8 liters/ha). Treatment $1=$ untreated; treatment $2=\mathrm{BZ}$; treatment $3=\mathrm{Q}$, week $1 / \mathrm{BZ}$ remaining; treatment $4=\mathrm{Q}$, weeks 1 and $3 / \mathrm{BZ}$ remaining; treatment $5=\mathrm{Q}$, weeks 1,3 , and $5 / \mathrm{BZ}$ remaining; treatment $6=\mathrm{Q}$, weeks $1,3,5$, and 7/BZ remaining; treatment $7=\mathrm{Q}$, weeks $1,3,5,7$, and 9/BZ remaining; treatment $8=\mathrm{Q}$, weeks $1,3,5,7-9 / \mathrm{BZ}$ remaining; treatment $9=\mathrm{Q}+\mathrm{BW}$, weeks 1,3 , and 5/BW remaining. tently associated with site-specific amino acid substitutions in the cytochrome $b$ gene. These were caused by three different SNPs at position 129 in cytochrome $b$, where phenylalanine is substituted with leucine. This study, in contrast to other studies $(5,18,25)$, indicates differences in codon substitutions responsible for the F129L mutation in A. solani. The results of this research and the statewide monitoring study during 2001 to 2003 (22) indicate that selection has occurred for a population of isolates with mean in vitro sensitivities to $\mathrm{AZ}\left(\mathrm{EC}_{50} \mathrm{~s}\right) 20$-fold higher than baseline isolates of A. solani collected in 1998. Mean sensitivity of $A$. solani isolates was not different between 2001, 2002, and 2003. During 2002 and 2003, there was no correlation between AUDPC values and mean sensitivity to AZ. Compared with 2001 and 2003, greater variations in $\mathrm{EC}_{50}$ values were observed among all fungicide treatments in 2002 (Table 1). This variation possibly is due to a variation in the recovery of wild-type $A$. solani isolates in plots treated with fungicides coupled with lower early blight disease severity and AUDPC values. Additionally a lack of statistical differences among all treatments was observed in 2002 due to high variability among replications. Although this trend was not consistent among years, no wildtype A. solani isolates were recovered in 2002 from experimental plots treated with AZ fungicide. Conversely, in 2001 and 2003, wild-type isolates were recovered from some but not all fungicide-treated plots. These results further reinforce the concept of a selective disadvantage for wild-type isolates of $A$. solani imposed by repeated fungicide applications regardless of how conducive the environmental conditions are for early blight.

Q-PCR assays performed on the 1998 baseline A. solani isolates indicated that all baseline isolates exhibited the wild-type genotype. None of the isolates collected in 1998, 2001, 2002, or 2003 exhibited mutations at position 143 in the cytochrome $b$ gene, including isolates with elevated in vitro $\mathrm{EC}_{50}$ values. In 2002, the frequency of wild types recovered from the Wisconsin statewide survey and experimental field populations was the same ( $4 \%$ of isolates). In contrast, no wild-type isolates were recovered in 2003 from commercial fields, but were present in our field experiments. Over the past five growing seasons (2000 to 2004), the efficacy of AZ has declined in fungicide evaluations (26-30), suggesting that a directional selection favoring a phenotype with a reduced response to $\mathrm{AZ}$ has occurred in populations of $A$. solani in Wisconsin subsequent to commercial release of Quadris. The fact that wild-type isolates of $A$. solani were recovered at a higher frequency from field research experiments than commercial fields suggests that the untreated guard rows in our fungicide trial plots provided a refuge for iso- 
lates sensitive to AZ. There was a statistical difference in the frequency of mutant types (TTA, CTC, and TTG) detected among selected treatments in 2001 and 2002 as well as between years at field trial sites. These results suggest that, as the selection pressure is maintained on $A$. solani isolates with a reduced sensitivity to $\mathrm{AZ}$, the frequency of TTG mutants may increase over CTC mutants; however, it remains unclear whether this is due to internal or external factors such as the cellular increase in mutant mitochondria or an influx from nearby grower's fields. However, results from statewide monitoring indicated that mean in vitro sensitivities to $\mathrm{AZ}$ ( $\mathrm{EC}_{50}$ values) among different mutant types were not significantly different from one another.

Results from the Q-PCR test were further confirmed by results of in vitro sensitivity tests demonstrating that $\mathrm{EC}_{50}$ values were lowest in the untreated control, $\mathrm{CH}$ alone, and three applications of AZ. This was due in large part to less variability in the range of $\mathrm{EC}_{50}$ values and a high frequency of recovery of isolates with sensitivity similar to baseline isolates collected prior to commercial use of QoIs. Effective disease control and a lower variability in $\mathrm{EC}_{50}$ values usually was achieved in all three growing seasons in field plots treated with $\mathrm{AZ}$ and $\mathrm{CH}$ alternations that strictly adhered to the current label requirements for the use of QoI fungicides on potato. These requirements include: follow resistant management guidelines and do not apply more than one application of Quadris or other group 11 (QoI) fungicides before alternation with a fungicide that is not in group 11. In light of the results from this research, commercial potato growers in Wisconsin have continued to integrate these concepts in resistance management strategies.

Results from this study and statewide monitoring (22) further confirmed that a directional selection favoring isolates of $A$. solani with a reduced response to $\mathrm{AZ}$ is associated with the F129L substitution. An amino acid substitution at position 129 from phenylalanine $(\mathrm{F})$ to leucine $(\mathrm{L})$ previously was shown to be responsible for a decrease in sensitivity to AZ in several fungal species, including $A$. solani $(5,18,25)$. Another amino acid substitution at position 143 from glycine $(\mathrm{G})$ to alanine (A) rendered isolates of several fungal species resistant to QoIs $(2,3,10,15)$. The F129L substitution generally causes a low magnitude decrease in sensitivity to QoIs or a reduced response ("intermediate resistance"), whereas the G143A substitution results in a high-magnitude decrease in sensitivity or no response ("resistant"). The reduced sensitivity responses in the sensitivity assay were associated consistently with molecular changes in the pathogen genome and vice versa. Thus, molecular probes may provide a reliable tool to quickly detect QoI resistance or reduced sensitivity in field isolates of $A$. solani in future studies and in the further design, testing, and implementation of effective and durable fungicide-resistant management strategies for the control of early blight.

It appears that the risk for evolution of resistance to QoI fungicides remains high in plant-pathogen populations, including foliar diseases (e.g., powdery mildews, downy mildews, and rusts), for which numerous and frequent application of fungicides is the primary means of control. Potato early blight likely will continue to be an annual production concern and, because control of this polycyclic disease depends on multiple fungicide applications, the selection pressure on $A$. solani for fungicide resistance likely will remain high not only in Wisconsin but throughout the United States. Practical fungicide resistance management strategies are important for the continued viability of $\mathrm{AZ}$ and other QoI fungicides used for the control of early blight. This project used a combination of fungicide efficacy field experiments, laboratory (in vitro) sensitivity assays, and molecular (Q-PCR) research to study the effects of fungicide resistance management tactics as an added component of control measures for early blight of potato. The study found that, in our experimental field evaluations, there remains a high frequency of $A$. solani isolates with reduced sensitivity to AZ. Further confirmation of the mechanism involved in reduced sensitivity to strobilurin fungicides in $A$. solani and the selection pressure imposed by increased applications of QoIs for the control of early blight provides a valuable baseline of information. Moreover, this study found no added benefit in disease control with more than three applications of AZ. This is the first study to test the impact of increased number of QoI applications on A. solani in controlled field experiments. Reducing the important economic risk due to decreased product efficacy that results from the evolution of fungicide resistance and subsequent unexpected control failures is useful for the commercial production of potato.

The data from this study highlight the impacts of selection for populations of $A$. solani isolates with a reduced response to AZ in Wisconsin relative to the 1998 baseline. This is similar to findings conducted in other potato production areas with a history of AZ use (18). Results from both the Q-PCR and the in vitro sensitivity assay are highly correlative, indicating that reduced sensitivity of $A$. solani to AZ is induced by a point mutation at position 129 of the cytochrome $b$ gene resulting in a change of the amino acid phenylalanine (F) to leucine (L). Further studies on the population biology of $A$. solani may be valuable in developing use recommendations for QoI fungicides in areas where isolates with decreased sensitivity have been detected. Additionally, studies on the possible selective disadvantage associated with wild-type isolates of $A$. solani in years when environmental conditions are not favorable for disease and pathogen dispersal deserve future consideration. This study is further confirmation that a reduction in the total number of AZ applications may result in a reduction of selection pressure for $A$. solani mutants with decreased sensitivity to AZ. Effective disease control typically was achieved when growers strictly adhered to the current Quadris label recommendations for the use of QoI fungicides. Therefore, if growers wish to continue using $\mathrm{AZ}$ and other QoI fungicides, it is recommended to (i) limit the number of QoI applications to onethird of the total number of sprays during a season; (ii) apply QoI fungicides early in the growing season alternated (no consecutive applications), tank mixed, or, when available, as prepack mixes with compounds of different chemistries; and (iii) never use QoI fungicides in a curative manner.

\section{ACKNOWLEDGMENTS}

This work was supported in part by Syngenta Crop Protection Inc., the Wisconsin Potato and Vegetable Growers Association, and the University of Wisconsin-Madison, College of Agriculture and Life Sciences. We thank A. Gargas, C. R. Grau, J. P. Helgeson, G. Jung, and P. S. McManus for critical review of this manuscript.

\section{LITERATURE CITED}

1. Anke, T. 1995. The antifungal strobilurins and their possible ecological role. Can. J. Bot. 73:S940-S945.

2. Avila-Cruz, A., Olaya, G., and Köller. W., 2003. Characterization of Colletotrichum graminicola isolates resistant to strobilurinrelated QoI fungicides. Plant Dis. 87:14261432.

3. Bartlett, D. W., Clough, J. M., Godwin, J. R., Hall, A. A., Hamer, M., and Parr-Dobrzanski, B. 2002. The strobilurin fungicides. Pest Manage. Sci. 58:649-662.

4. Brasseur, G., Saribas, A. S., and Daldal, F. 1996. A compilation of mutations located in the cytochrome $b$ subunit of the bacterial and mitochondrial $b c 1$ complex. Biochim. Biophys. Acta. 1275:61-69.

5. Chin, K. M., Chavaillaz, D., Kaesbohrer, M., Staub, T., and Felsenstein, F. G. 2001. Characterizing resistance risk of Erysiphe graminis $\mathrm{f}$. sp. tritici to strobilurins. Crop Prot. 20:87-96.

6. Degli Esposti, M., de Vries, S., Crimi, M. Ghelli, A., Patarnello, T., and Meyer, A. 1993. Mitochondrial cytochrome $b$ : evolution and structure of the protein. Biochim. Biophys. Acta 1143:243-271.

7. Di Rago, J. P., Coppée, J. Y., and Colson, A. M. 1989. Molecular basis for resistance to myxothiazol, mucidin (strobilurin A), and stigmatellin. J. Biol. Chem. 264:14543-14548.

8. Geier, B. M., Schägger, H., Brandt, U., Colson, A. M., and von Jagow, G. 1992. Point mutation in cytochrome $b$ of yeast ubihydroquinone: cytochrome- $c$ oxidoreductase causing myxothiazol resistance and facilitated dissociation of the iron-sulfur subunit. Eur. J. Biochem. 208:375-380.

9. Gisi, U, Chin, K M, Knapova, G, Farber, R Kung, Mohr, U, Parisi, S, Sierotzki, H, and Steinfeld, U. 2000. Recent developments in 
elucidating modes of resistance to phenylamide, DMI and strobilurin fungicides. Crop Prot. 19:863-872.

10. Ishii, H., Fraaije, B. A., Sugiyama, T., Noguchi, K., Nishimura, K., Takeda, T., Amano, T., and Hollomon, D. W. 2001. Occurrence and molecular characterization of strobilurin resistance in cucumber powdery mildew and downy mildew. Phytopathology 91:1166-1171.

11. Jordan, D. B., Livingston, R. S., Bisaha, J. J., Duncan, K. E., Pember, S. O., Picollelli, M. A., Schwartz, R. S., Sternberg, J. A., and Tang, X. S. 1999. Mode of action of famoxadone. Pestic. Sci. 55:105-118.

12. Jordan, D. B., Livingston, R. S., Bisaha, J. J., Duncan, K. E., Pember, S. O., Picollelli, M. A., Schwartz, R. S., Sternberg, J. A., and Tang, X. S. 1999. Oxazolidinones: a new chemical class of fungicides and inhibitors of mitochondrial cytochrome $b c 1$ function. Pestic. Sci. 55:213215.

13. Kim, Y. S., Dixon, E. W., Vincelli, P., and Farman, M. L. 2003. Field resistance to strobilurin (QoI) fungicides in Pyricularia grisea caused by mutations in the mitochondrial cytochrome $b$ gene. Phytopathology 93:891900.

14. Küng Färber, R., Chin, K. M., and Leadbitter, N. 2002. Sensitivity of Venturia inaequalis to trifloxystrobin. Pest Manage. Sci. 58:261-267.

15. Ma, Z., Felts, D., and Michailides, T. J. 2003. Resistance to azoxystrobin in Alternaria isolates from pistachio in California. Pestic. Bio- chem. Physiol. 77:66-74

16. Olaya, G., and Köller, W. 1999. Baseline sensitivities of Venturia inaequalis populations to the strobilurin fungicide kresoxim-methyl. Plant Dis. 83:274-278.

17. Olaya, G., Cleere, S., Stanger, C., Burbidge, J., Hall, A., and Windass, J. 2003. A novel potential target site of QoI fungicide resistance mechanism in Pythium aphanidermatum. (Abstr.) Phytopathology 93:S67.

18. Pasche, J. S., Piche, L. M., and Gudmestad, N. C. 2005. Effect of the F129L mutation in Alternaria solani on fungicides affecting mitochondrial respiration. Plant Dis. 89:269-278.

19. Pscheidt, J. W. 1986. Early blight of potato and tomato: a literature review. Univ. Wis. Ext. Coop. Ext. Serv. 3376. Research Division of the College of Agriculture and Life Sciences University of Wisconsin-Madison, Madison, WI

20. Reschke, M. 1999. Strobis in Gefahr. Dtsch. Landwirtsch. Ges. Mitt. 1:51.

21. Rosenzweig, N., and Stevenson, W. R. 2003. Sensitivity of Alternaria solani to azoxystrobin. (Abstr.) Phytopathology 93:S75.

22. Rosenzweig, N., and Stevenson, W. R. 2004. Tracking changes in sensitivity of Alternaria solani to azoxystrobin in WI. (Abstr.) Phytopathology 94:S161.

23. Rotem, J. 1994. The Genus Alternaria: Biology, Epidemiology, and Pathogenicity. American Phytopathological Society Press, St. Paul, $\mathrm{MN}$
24. Shahin, E. A., and Shepard, J. F. 1979. An efficient technique for inducing profuse sporulation of Alternaria species. Phytopathology 69:618-620.

25. Sierotzki, H., Wullschleger, J., and Gisi, U. 2000. Point mutation in cytochrome $b$ gene conferring resistance to strobilurin fungicides in Erysiphe graminis f. sp. tritici field isolates. Pestic. Biochem. Physiol. 68:107-112.

26. Stevenson, W. R., and James, R. V. 2000 Evaluation of fungicides to control potato early blight and late blight, 1999. Fungic. Nematicide Tests 55:228.

27. Stevenson, W. R., and James, R. V. 2001 Evaluation of fungicides to control potato early blight and late blight, 2000. Fungic. Nematicide Tests 56:V53.

28. Stevenson, W. R., and James, R. V. 2002 Evaluation of fungicides to control potato early blight and late blight 2001. Fungic. Nematicide Tests 57:V072:1-3

29. Stevenson, W. R., and James, R. V. 2003 Evaluation of fungicides to control early blight and late blight of potato, Hancock, 2002. Fungic. Nematicide Tests 58:V046:1-3.

30. Stevenson, W. R., and James, R. V. 2004. Evaluation of fungicides to control early blight of potato, Hancock, WI 2003. Fungic. Nematicide Tests 59:V040:1-2.

31. Ziogas, B. N., Baldwin, B. C., and Young, J. E. 1997. Alternative respiration: a biochemical mechanism of resistance to azoxystrobin (ICIA 5504) in Septoria tritici. Pestic. Sci. 50:28-34. 